\title{
Oil Below Tarmat/Water Contact: Ramification of Structural Evolution of Minagish Oolite, Minagish Oil Field, Kuwait
}

\author{
${\text { Muhammad W. } \text { Ibrahim }^{1 *} \text { and Tahir El Gezeery }}^{2}$ \\ ${ }^{1}$ Target Exploration. \\ ${ }^{2} \mathrm{KOC}$. \\ *Corresponding Author: m.ibrahim@targetexploration.com
}

A study of the structural evolution of Minagish Oil Field revealed that the trapping anticline began in Early Cretaceous time as a minor dome at the SSE flank of a NW-trending larger Jurassic anticline.

The Berriasin Minagish Oolite Member of Minagish Formation of the Minagish Field assumed its present-day anticlinal motif by Maastrichtian time, then gently tilted towards the NNE and got dissected by an E-W fault during Tertiary times. The Tertiary fault compartmentalised the Minagish Oolite reservoir into two main compartments: an up-thrown symmetrical northern compartment, and a wrenched and down-thrown asymmetrical southern compartment.

The incipient Minagish structure affected the thickness and deposition of the oolitic facies of Minagish Oolites Member. Subsequent regional NNE tilts had a minor effect on shifting the position of superior oolitic facies in relation to present-day structural peaks of the Minagish Oolite reservoir. However, Tertiary differential displacement of the two main compartments influenced the thickness and position of the occluded tarmat zones, and preserved a record of reservoir's Tertiary oil/water contacts.

The structural evolution of the Minagish Oolite explains the preservation of sealing tarmat zones within the superior oil-bearing reservoir facies above and below the present-day oil/water contact in the northern compartment, and the preservation of tarmat zones within the relatively inferior and water-bearing facies below present-day oil/water contact in the southern sector of the Minagish Oolite reservoir.

This relationship migrates from the geometrical motif of the early development team of simple oil/tarmat/water contacts, into oil/tarmats/oil/tarmats/water contacts in the northern compartment versus oil/water/tarmats/water contacts in the southern main compartment.

Technically there is producible oil below the perceived early development maximum depth of the single tilted tarmat/water contact. The oil is heavier than the main oil within the higher main reservoir, it may have been sealed by tarmat zones (as a combination? or diagenetic? trap), and it is below the perceived single early development tilted tarmat/water contact in the northern sector of the Minagish Oolite reservoir of Minagish oil field. 